Supporting Information

\title{
Copper-Activated DNA Photocleavage by a Pyridine-Linked Bis-Acridine Intercalator
}

\author{
María-José Fernández, ${ }^{\dagger}$ Beth Wilson, ${ }^{\ddagger}$ Marta Palacios, ${ }^{\dagger}$ María-Melia \\ Rodrigo, ${ }^{\S}$ Kathryn B. Grant ${ }^{\ddagger, *}$ and Antonio Lorente ${ }^{\dagger, *}$ \\ †Departamento de Química Orgánica and ${ }^{\S}$ Departamento de Química- \\ Física, Universidad de Alcalá, 28871-Alcalá de Henares, Madrid, Spain. \\ ${ }^{\star}$ Department of Chemistry, Center for Biotechnology and Drug Design, \\ Georgia State University, P.O. Box 4098, Atlanta, Georgia 30303-4098, \\ U.S.A.
}

\section{Contents:}

Table S1: The $\lambda_{\max }$ values and extinction coefficients of nucleic acid samples used in competition dialysis experiments.

Figure S1: ESI mass spectra of compound 4 and of 1:1 metallic complexes formed between compound $\mathbf{4}$ and $\mathrm{Cu}(\mathrm{II})$.

Figure S2: Concentration profile: percent photocleavage of pUC19 plasmid DNA in the absence and presence of $50 \mu \mathrm{M}$ to $2 \mu \mathrm{M}$ concentrations of $\mathrm{CuCl}_{2}$ and/or compound 4 .

Figure S3: Storage-phosphor autoradiogram of a 10.0\% denaturing polyacrylamide gel showing DNA photocleavage products at nucleotide resolution. 
Table S1. Nucleic Acid Samples Used in Competition Dialysis Experiments ${ }^{a}$

\begin{tabular}{lcc}
\hline deoxyribonucleic acid & $\lambda(\mathrm{nm})$ & $\varepsilon\left(\mathrm{M}^{-1}(\mathrm{bp}) \mathrm{cm}^{-1}\right)$ \\
\hline [poly(dGdC) $]_{2}(100 \% \mathrm{GC})$ & 254 & 16,800 \\
ML DNA (72\% GC) & 260 & 13,846 \\
CT DNA (42\% GC) & 260 & 12,824 \\
CP DNA (31\% GC) & 260 & 12,476 \\
poly(dA)-poly(dT) (0\%GC) & 260 & 12,000 \\
[poly(dAdT) $]_{2}(0 \%$ GC) & 262 & 13,200 \\
${ }^{a} \varepsilon \quad$ is the molar extinction coefficient at the \\
wavelength $\lambda$, expressed in terms of DNA base pairs.
\end{tabular}




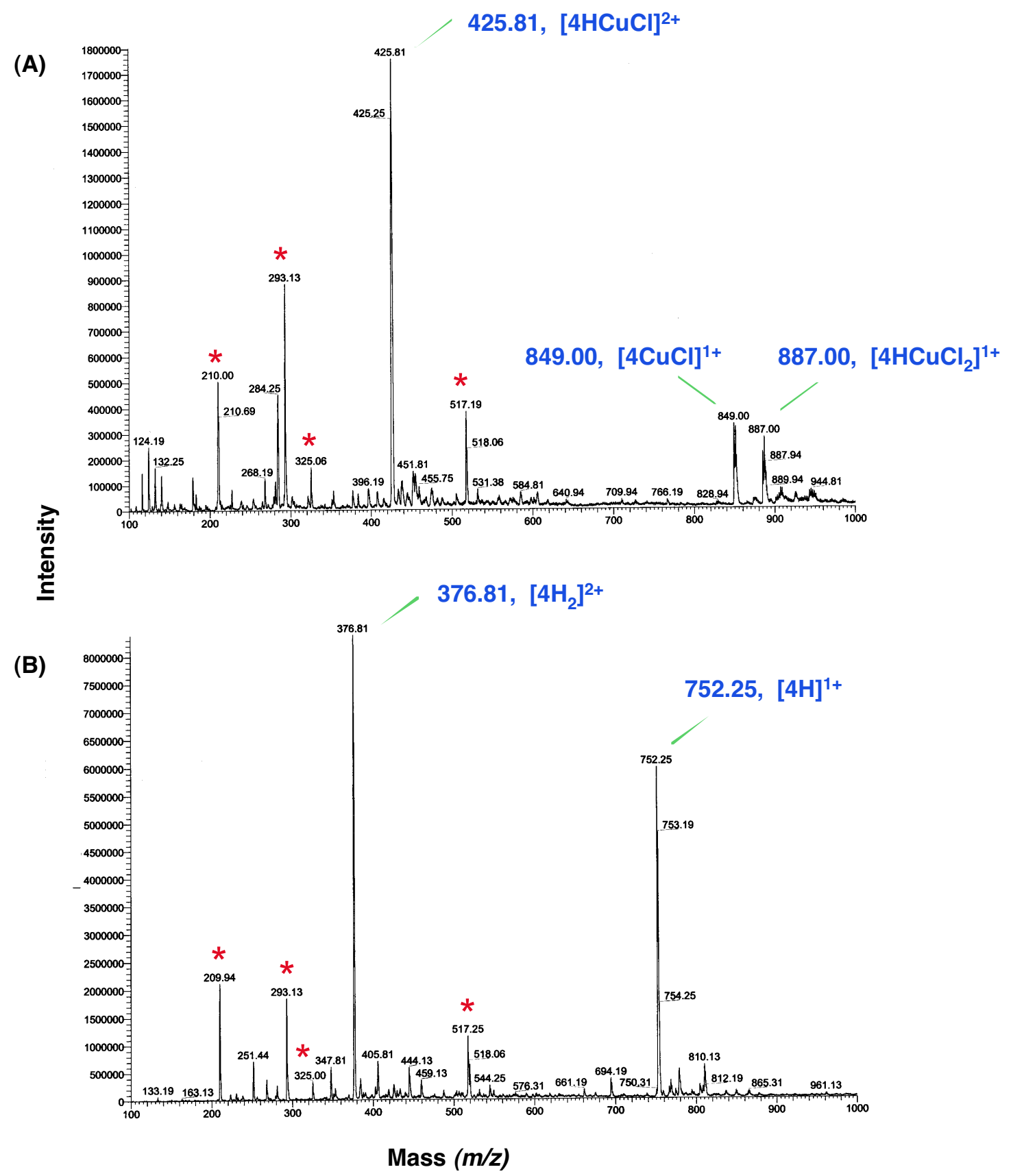

Figure S1. (A) Positive ion ESI mass spectrum showing complexes formed between ligand 4 and $\mathrm{CuCl}_{2}$ in HPLC-grade methanol at a ligand to metal ratio of 1:1. Isotopic distributions of molecular ions corresponding to the following 1:1 metallic complexes are observed: (i) $[4 \mathrm{HCuCl}]^{2+}$ between 425 and 428 $\mathrm{m} / z$ (calcd for $\left[\mathrm{C}_{43} \mathrm{H}_{46} \mathrm{~N}_{9} \mathrm{O}_{4} \mathrm{CuCl}\right]^{2+} 425.13$ ); (ii) $[4 \mathrm{CuCl}]^{1+}$ between 849 and $855 \mathrm{~m} / z$ (calcd for $\left[\mathrm{C}_{43} \mathrm{H}_{45} \mathrm{~N}_{9} \mathrm{O}_{4} \mathrm{CuCl}\right]^{1+} 849.26$ ); (iii) $\left[4 \mathrm{HCuCl}_{2}\right]^{1+}$ between 885 and $892 \mathrm{~m} / z$ (calcd for $\left[\mathrm{C}_{43} \mathrm{H}_{46} \mathrm{~N}_{9} \mathrm{O}_{4} \mathrm{CuCl}_{2}\right]^{1+}$ 885.24). (B) Positive ion ESI mass spectrum of ligand 4 in HPLC grade methanol (no $\mathrm{CuCl}_{2}$ ). The following isotopic distributions of molecular ions corresponding to ligand 4 are observed: (i) $\left[4 \mathrm{H}_{2}\right]^{2+}$ between 377 and $378 \mathrm{~m} / z$ (calcd for $\left[\mathrm{C}_{43} \mathrm{H}_{47} \mathrm{~N}_{9} \mathrm{O}_{4}\right]^{2+}$ 376.69); (ii) $[4 \mathrm{H}]^{1+}$ between 752 and $755 \mathrm{~m} / z$ (calcd for $\left[\mathrm{C}_{43} \mathrm{H}_{46} \mathrm{~N}_{9} \mathrm{O}_{4}\right]^{1+}$ 752.37). A comparison of the spectra shows that there is no evidence of free ligand 4 in (A). The asterisk identifies peaks in common to both spectra. 


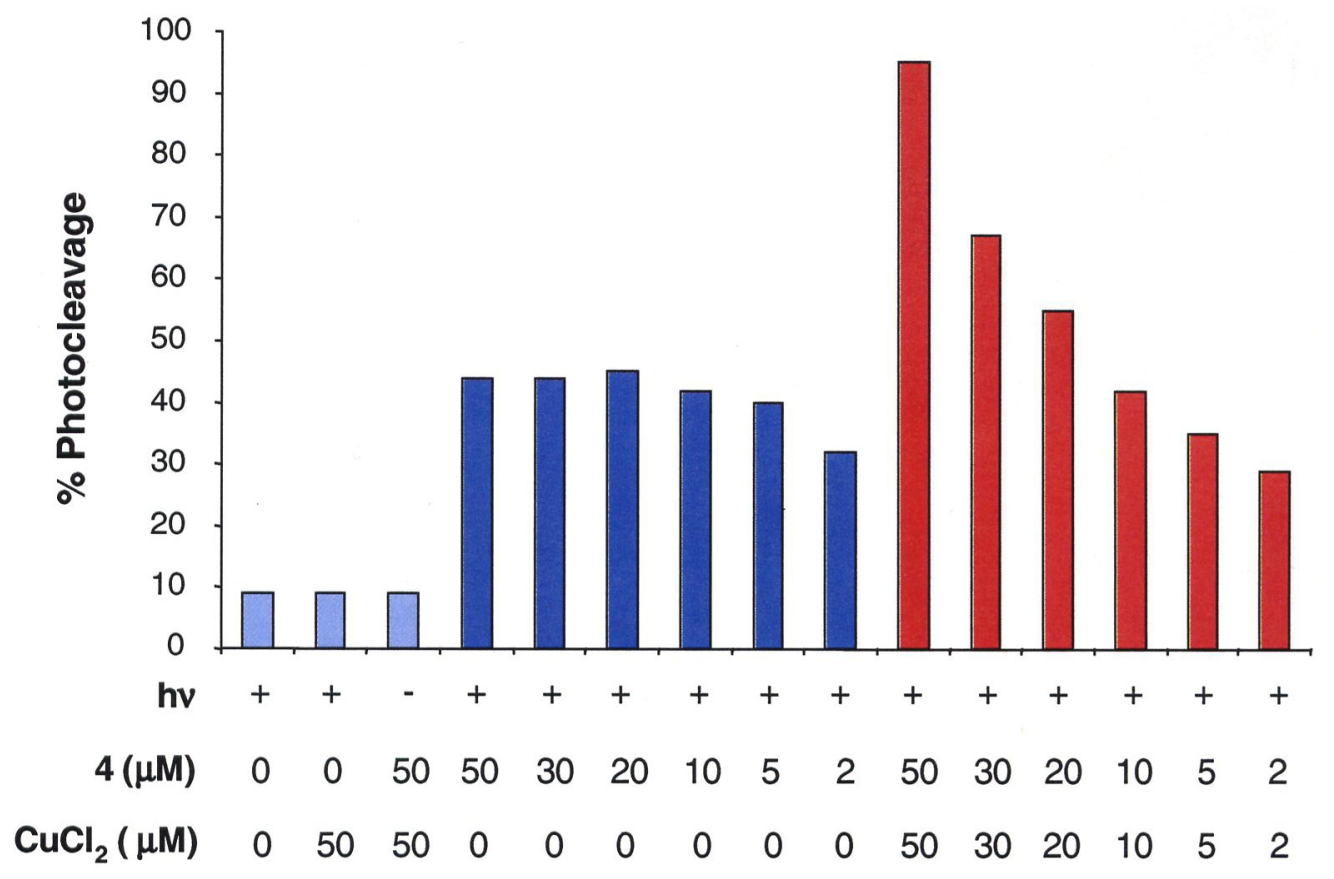

Figure S2. Concentration profile: percent photocleavage of pUC19 plasmid DNA. Reactions contained $20 \mathrm{mM}$ sodium phosphate buffer $\mathrm{pH} 7.0$ and $38 \mu \mathrm{M}$ bp DNA without and with $50 \mu \mathrm{M}$ to $2 \mu \mathrm{M}$ concentrations of $\mathrm{CuCl}_{2}$ and/or compound 4 . The samples were aerobically irradiated at $419 \mathrm{~nm}$ for 50 min at $22{ }^{\circ} \mathrm{C}$. The results showed that nicked DNA was the exclusive cleavage product, with the exception of the reaction irradiated in the presence of $50 \mu \mathrm{M}$ of $\mathrm{CuCl}_{2}$ and $50 \mu \mathrm{M}$ of compound 4 . (In this reaction, nicked and linear DNA forms were produced in $87 \%$ and $8 \%$ yield, respectively.) 


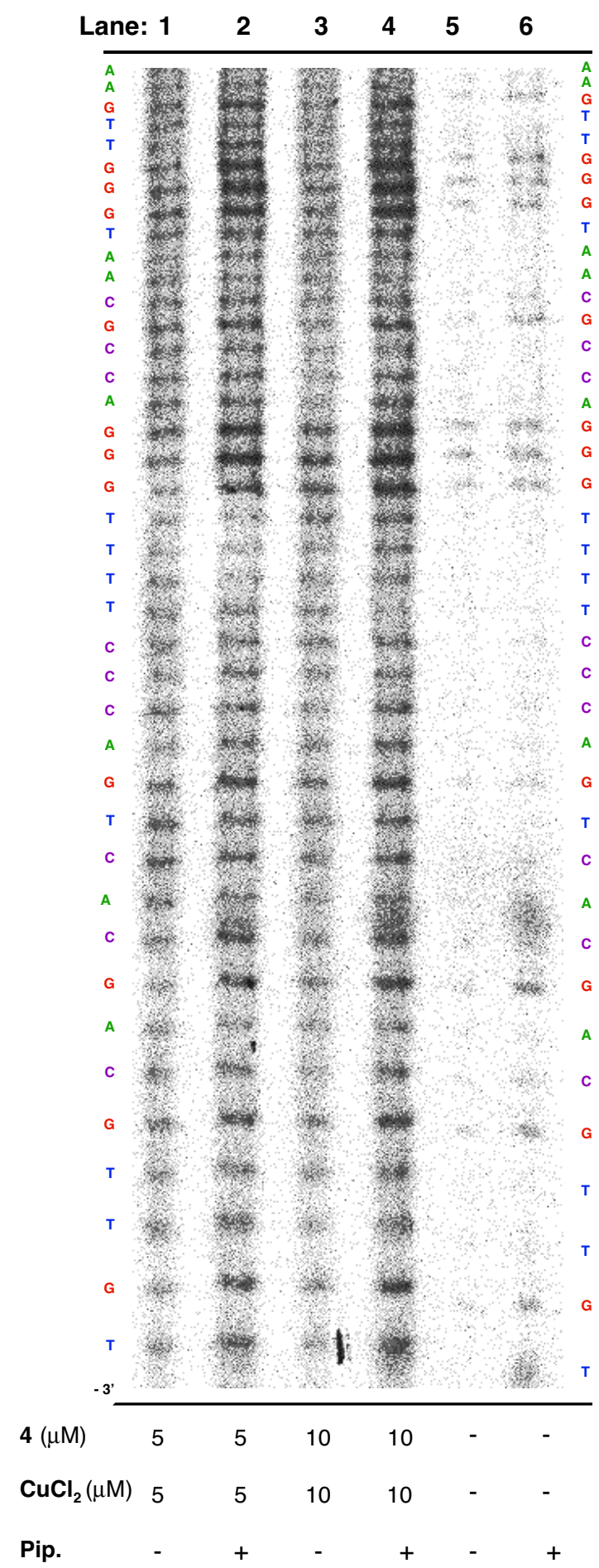

Figure S3 . A storage-phosphor autoradiogram of DNA photocleavage products resolved on a $10.0 \%$ denaturing polyacrylamide gel. Shown in the gel is a representative $40 \mathrm{bp}$ sequence within an ${ }^{35} \mathrm{~S} 3$ '-end labeled $138 \mathrm{bp}$ restriction fragment from pUC19. Lanes 1, 2: $15 \mu \mathrm{M}$ bp of the restriction fragment irradiated at $419 \mathrm{~nm}$, in the presence of $5 \mu \mathrm{M} 4$ and $5 \mu \mathrm{M} \mathrm{CuCl}_{2}$, without and with subsequent piperidine treatment. Lanes 3, 4: $15 \mu \mathrm{M}$ bp of the restriction fragment irradiated in the presence of $10 \mu \mathrm{M} 4$ and 10 $\mu \mathrm{M} \mathrm{CuCl}_{2}$, without and with subsequent piperidine treatment. Lanes 5, 6: $15 \mu \mathrm{M}$ bp of the restriction fragment irradiated without and with subsequent piperidine treatment (no 4, no $\mathrm{CuCl}_{2}$ ). DNA bases are identified to the right and left of the gel. To produce the cleavage plot shown in Figure 7A of the accompanying manuscript, Lane $5(f \mathrm{c})$ was subtracted from Lane $1(f \mathrm{a})$. To produce the cleavage plot shown in Figure 7B of the accompanying manuscript, Lane $6(f \mathrm{c})$ was subtracted from Lane $2(f \mathrm{a})$. 